\title{
Correction to: Rarely occurring mutation of ACVR1 gene in Moroccan patient with fibrodysplasia ossificans progressiva
}

\author{
Ilham Ratbi ${ }^{1,2} \cdot$ Renata Bocciardi $^{3} \cdot$ Asmaa Regragui $^{1}$. \\ Roberto Ravazzolo ${ }^{4}$ Abdelaziz Sefiani ${ }^{1,2}$
}

Published online: 13 November 2017

(C) International League of Associations for Rheumatology (ILAR) 2017

Correction to: Clin Rheumatol (2010) 29:119-121

https://doi.org/10.1007/s10067-009-1283-z

The original version of this article, unfortunately, contained an error.

One of the author's name on this article was incorrectly spelled as "Renata Borcciadi". The correct spelling is "Renata Bocciardi" and is now presented correctly in this article.

The online version of the original article can be found at https://doi.org/ 10.1007/s10067-009-1283-z

Ilham Ratbi

ilhamratbi@yahoo.fr

1 Department of Medical Genetics, National Institute of Health, 27 Avenue Ibn Batouta, BP 769, 11400 Rabat, Morocco

2 Faculty of Medicine and Pharmacy, University Mohamed V, Human Genomic Center, Rabat, Morocco

3 Laboratory of Molecular Genetics, G Gaslini Institute, Genoa, Italy

4 Department of Pediatrics and CEBR, University of Genova, Genoa, Italy 